\title{
Energy and protein nutrition of early-weaned pigs. 2. Effect of energy intake and energy: protein on energy utilisation and body composition of pigs slaughtered at $32 \mathrm{~d}$
}

\author{
BY K. J. MCCRACKEN \\ Agricultural and Food Chemistry Research Division, \\ Department of Agriculture, Northern Ireland and \\ The Queen's University of Belfast, Newforge Lane, \\ Belfast BT9 ${ }_{5} P X, N$. Ireland \\ AND S. M. EDDIE* \\ Agricultural Research Institute of Northern Ireland \\ Hillsborough, Co Down, N. Ireland \\ AND W. G. STEVENSON \\ Biometrics Division, Department of Agriculture, \\ Newforge Lane, Belfast BT9 $5 P X, N$. Ireland
}

\section{(Received 13 June 1979 - Accepted I August 1979)}

1. The effect of energy and protein intake on the nitrogen and energy utilization and carcass composition of artificially-reared pigs was studied between 8 and $32 \mathrm{~d}$ of age in an experiment employing a $5 \times 3 \times 2$ factorial design. The factors were initially energy: $N$ value (I) $(250,355,460,565$ or $670 \mathrm{~kJ} / \mathrm{g} \mathrm{N})$, rate of increase of $I(R)$ at $8 \mathrm{~d}$ intervals $(0,12.5$ or $25 \%$ ) and plane of nutrition (three times daily to appetite or $75 \%$ of this intake).

2. The range of energy: $\mathbf{N}$ values was obtained by formulating five diets based on dried skim milk, lactose and casein and feeding appropriate combinations of two diets.

3. The metabolizable energy (ME) intake, carcass dry matter (DM) content, carcass protein gain and carcass fat gain exhibited significant $(P<0.001)$ quadratic responses to $I$.

4. The carcass fat content in the DM increased from 200 to $342 \mathrm{~g} / \mathrm{kg}(P<0.001)$ and the carcass crude protein $(\mathrm{N} \times 6.25)$ content decreased from 657 to $519 \mathrm{~g} / \mathrm{kg}$ with increasing level of I $(P<0.00 \mathrm{I})$. The fat and protein contents were 309 and $556 \mathrm{~g} / \mathrm{kg}$ and 242 and $610 \mathrm{~g} / \mathrm{kg}$ respectively on the high and low plane of nutrition (PN) and were significantly different $(P<0.001)$.

5. There was a significant $I \times R$ interaction in relation to carcass protein gain with the maximum gain occurring at $460 \mathrm{~kJ} / \mathrm{g} \mathrm{N}$ when I was constant and at $355 \mathrm{~kJ} / \mathrm{g} \mathrm{N}$ when $R$ was $25 \%$ per $8 \mathrm{~d}$.

6. The proportion of apparent digested $\mathrm{N}$ intake retained ( $\mathrm{N}$ retention (NR):apparent digested $\mathrm{N}(\mathrm{ADN})$ ) was significantly $(P<0.001)$ affected by all three factors and there were significant $I \times R(P<0.001)$, $I \times P N(P<0.01)$ and $R \times R \times P N(P<0.01)$ interactions. The maximum value of NR:ADN was 0.80 .

7. Carcass fat gain and carcass energy gain exhibited quadratic responses to I reaching maximum values at $460 \mathrm{~kJ} / \mathrm{g} \mathrm{N}$. The energy content of the live-weight gain increased linearly $(P<0.001)$ from 5.79 to 7.90 $\mathrm{MJ} / \mathrm{kg}$ with increasing level of I. PN and R also produced significant $(P<0.00 \mathrm{I})$ responses the means being respectively 7.52 and $6.39 \mathrm{MJ} / \mathrm{kg}$ on the high and low $P N$ and $6.55,6.94$ and $7.38 \mathrm{~kJ} / \mathrm{kg}$ with increasing value of $\mathbf{R}$.

8. Multiple regression analysis of ME intake on live-weight (W), protein gain (PG) and fat gain (FG) yielded the equation:

$$
M E(M J)=0.644 W^{0.75}+32 \cdot 6 \mathrm{PG}+48 \cdot 2 \mathrm{FG} .
$$

This result is discussed in relation to published values for the energy requirements of the young pig.

It is generally accepted that dietary protein and energy intake affect the body composition of growing animals (Breirem \& Homb, 1972). In the young pig, fat:protein and the energy content of the live-weight gain increase as the dietary protein content is reduced (Schneider \& Sarett, 1969; Kirchgessner \& Kellner, 1972; Newport, 1979). Hiowever, the extent of - Present address: BOCM-Silcock Ltd, BOCM-Silcock House, Basing View, Basingstoke RG2I 2EQ, Hants. 


\section{K. J. McCracken. S. M. Eddie and W. G. Stevenson}

the changes in relation to a wide spectrum of protein intakes and the interaction of protein and energy intake have not been clearly defined. The experiment described by McCracken et al. (1980) provided an opportunity to examine the effect of these two factors on the body composition of pigs at $32 \mathrm{~d}$. In addition it afforded a comparison of the retention of protein between 8-32 d as determined by the slaughter method with that obtained by nitrogen balance. It is well known that large discrepancies may arise between results obtained by balance and slaughter (Nehring et al. 1957; Duncan, 1966; Fuller \& Boyne, 1971). Whilst in the paper of McCracken et al. (1980) absolute values for $\mathrm{N}$ retention were of secondary importance to the shape of the response curves in estimating the requirement for protein it was realized that, if the error incurred with the balance method changed with the level of dietary protein, the shape of the response curves and hence the validity of the estimates of dietary protein requirement could be in doubt.

Few estimates of the maintenance requirement and efficiency of utilization of energy for growth in the young pig have been reported. Kielanowski (1965) applied multiple regression analysis to the results for eight pigs reared from 2.5 to $8.5 \mathrm{~kg}$ and reported values of $7.5 \mathrm{I}$ and II $75 \mathrm{kcal}(3 \mathrm{I} \cdot 5$ and $48.9 \mathrm{~kJ} / \mathrm{g}$ ) for the energy cost of protein and fat deposition respectively. From Kielanowski's (1965) results it is possible to calculate the maintenance requirement as $575 \mathrm{~kJ} / \mathrm{kg}$ body-weight $\mathrm{W}^{\mathbf{0 . 7 5}}$. However, Kielanowski \& Kotarbinska (1970) re-analysed the results assuming a high efficiency of fat deposition and concluded that the maintenance requirement ( $\mathrm{M}: \mathrm{kJ}$ ) lay between 450 and $500 \mathrm{~kg} \mathrm{W0.75}$ and the energy cost of protein deposition between 42 and $48 \mathrm{~kJ} / \mathrm{g}$. Muller \& Kirchgessner (1974) were unable to use multipleregression techniques due to the small range of body-weight of the experimental animals but on the basis of a range of assumed values for maintenance requirement and efficiency of fat deposition, estimated the energy cost of protein deposition to be between 44 and 57 $\mathrm{kJ} / \mathrm{g}$ over the 4-12 kg live-weight range. Jordan \& Brown (I970) using indirect calorimetry found the maintenance requirement of pigs aged I 5-39 d to be between 500 and $540 \mathrm{~kJ} / \mathrm{kg}$ $W^{0.75}$.

In order to obtain reasonably precise estimates of maintenance requirement and efficiency of protein and fat deposition using multiple-regression techniques, it is desirable to have a wide range of inputs for the various terms. The combination of treatments described by McCracken et al. (1980) brought about a fairly wide range of live-weight and food intake and could also be reasonably expected to produce a range of rates of protein and fat deposition. It therefore afforded the opportunity for a comprehensive study of maintenance requirement and efficiency of energy utilization in the young pig using multiple-regression techniques.

EX PERIMENTAL

Experimental design

The experiment was conducted as a $5 \times 3 \times 2$ factorial, the factors being initial energy: $N$ value (I, $\mathrm{kJ} / \mathrm{g} \mathrm{N} ; 250,355,460,565$ or 670$)$, rate of increase of $\mathrm{I}(\mathrm{R})$ at $8 \mathrm{~d}$ intervals $(\% \mathrm{I}$; $0,12.5$ or 25 ) and plane of nutrition (PN; three times daily to appetite or $75 \%$ of this intake). The details of the experimental layout, diets and piglet management have been described previously (McCracken et al. 1980).

\section{Initial carcass composition}

It was originally intended to slaughter thirty pigs at $8 \mathrm{~d}$ (six per replicate). However, only thirty-six cages were available and in each replicate, some of the pigs died or had to be discarded before $8 \mathrm{~d}$ of age with the result that only thirteen pigs were available for initial carcass analysis. At $8 \mathrm{~d}$ of age all the surviving pigs were weighed and the thirty treatments 
were randomized over the cage positions. The spare pigs were immediately slaughtered and stored at $-20^{\circ}$ for subsequent analysis.

\section{Slaughter at $32 \mathrm{~d}$}

At $32 \mathrm{~d}$ of age the pigs were taken off balance at around 09.00 hours, weighed and slaughtered. The gut contents were removed and the empty gut, blood and eviscerated carcass were weighed together and stored at $-20^{\circ}$ for subsequent analysis.

\section{Preparation of carcasses for analysis}

The carcasses were prepared for analysis by mincing, homogenizing and freeze-drying using a slight modification of the procedure of Florence \& Mitchell (1972) as described by Jordan \& Weatherup (1976a). The freeze-dried material was allowed to equilibrate under normal laboratory conditions of temperature and humidity before being weighed. It was then milled in a Moulinex grinder.

\section{Analytical methods}

The dry matter (DM) content of milled carcass was determined in a forced-draught oven at $100^{\circ}$. Crude protein $(\mathrm{N} \times 6.25)$ was determined on 2-3 g samples of the milled carcass by the macro-Kjeldahl method using $0.5 \mathrm{M}$-acid and alkali, carcass fat by the Soxhlet method using $40-60^{\circ}$ b.p. petroleum spirit and the mineral content was measured by ashing at $45^{\circ}$ in a muffle furnace.

Carcass energy content was calculated from the weights of crude protein, using the factor $23.8 \mathrm{MJ} / \mathrm{kg}$ (Brouwer, 1965), and of fat using the factor $38.91 \mathrm{MJ} / \mathrm{kg}$. The fat factor was determined on carcass extracts using an adiabatic bomb calorimeter.

\section{Calculation of metabolizable energy (ME) intake}

The energy contents of samples of freeze-dried faeces were determined for each balance period for all replicates using an adiabatic bomb calorimeter. The digested energy intake for each $8 \mathrm{~d}$ period was calculated by multiplying the gross energy intake by the digestibility obtained during the balance period. Urine energy was determined for the first replicate only. A regression equation of energy content on $\mathrm{N}$ content was calculated for each balance period and in subsequent replicates the urine energy content was calculated from urine $\mathrm{N}$ content.

\section{Calculation of mean body-weight and metabolic body-weight}

The mean weight of each pig over the experimental period was estimated on a daily basis from the $4 \mathrm{~d}$ weights and the daily metabolic body-weight $\left(\mathrm{kg} \mathrm{W}^{0.75}\right.$ or $\left.\mathrm{kg} \mathrm{W}^{0.56}\right)$ was computed and integrated over the experimental period for the calculation of mean metabolic body size.

\section{RESULTS}

The range of body-weights of the pigs slaughtered at $8 \mathrm{~d}$ was $1 \cdot 2-2 \cdot 5 \mathrm{~kg}$ and the mean weight was $\mathrm{I} .89 \mathrm{~kg}$. The average carcass composition $(\mathrm{g} / \mathrm{kg})$ was $249 \mathrm{DM}, 157$ crude protein and 62 fat. Carcass crude protein content was unaffected by body-weight but DM content and fat content were significantly $(P<0.001)$ correlated with body-weight. The regression equations were respectively:

and

$$
\begin{aligned}
& D=202.6+24.8( \pm 2.58) W, r 0.945 \\
& F=13.14+25.67( \pm 5.6 \mathrm{I}) W, r 0.810,
\end{aligned}
$$

where $D$ is the DM content $(\mathrm{g} / \mathrm{kg}), F$ is the fat content $(\mathrm{g} / \mathrm{kg})$ and $W$ is the weight $(\mathrm{kg})$. 


\section{K. J. MCCracken, S. M. Eddie and W. G. Stevenson}

The intake of ME (Table I) was significantly affected $(P<0.001)$ by $I$ and by PN. The response to I was significantly quadratic $(P<0.00 I)$ and there was a significant $(P<0.05)$ $I \times R$ interaction in that the maximum intake occurred with an energy: $N$ value of 460 $\mathrm{kJ} / \mathrm{g} \mathrm{N}$ when the same diet was fed from 8 to $32 \mathrm{~d}$ but with an I value of $355 \mathrm{~kJ} / \mathrm{g} \mathrm{N}$ when energy: $\mathrm{N}$ increased by $25 \% / 8 \mathrm{~d}$. On the high PN the daily ME intake attained a maximum of approximately $5.5 \mathrm{MJ}$.

The response of carcass DM content to I (Table 2$)$ was significantly quadratic $(P<0.001)$. There was also a significant $(P<0.001)$ response to $P N$, the means for the high and low energy intakes being, respectively 290 and $270 \pm 1.5 \mathrm{~g} / \mathrm{kg}$. The crude protein content and fat content in the DM were significantly affected by $I(P<0.00 I)$ and in the instance of the crude protein content there was a significant quadratic response $(P<0.05)$. Increasing $\mathrm{R}$ increased carcass fat content and reduced protein content $(P<0.001)$ the means being respectively 250,279 and $298 \pm 4.4 \mathrm{~g} / \mathrm{kg}$ for fat and 607,579 and $562 \pm 4.0 \mathrm{~g} / \mathrm{kg}$ for protein with increasing levels of $R$. There were no significant treatment interactions in respect of carcass DM content or the proportion of fat and protein in the DM.

Carcass DM gain (Table 3 ) paralleled the intake of ME and showed a quadratic response to $\mathbf{I}(P<0.001)$ but was unaffected by $\mathrm{R}$. There was a significant $\mathrm{I} \times \mathrm{R}$ interaction $(P<0.05)$, the maximum gains being achieved with an energy: $N$ value of $460 \mathrm{~kJ} / \mathrm{g} \mathrm{N}$ when $R$ was zero and with an I value of $355 \mathrm{~kJ} / \mathrm{g} \mathrm{N}$ when $\mathrm{R}$ was $25 \% / 8 \mathrm{~d}$. The mean values for the high and low PN were 1.76 and $1.25 \mathrm{~kg}$ and were significantly different $(P<0.00 \mathrm{I})$.

Carcass protein gain (Table 4$)$ exhibited a quadratic response to I $(P<0.001)$ and was significantly affected by $\mathrm{R}(P<0.001)$ and $\mathrm{PN}(P<0.001)$. However, the reduction in carcass protein gain on the low energy intake was less than the reduction in DM gain, the over-all means being 0.94 and $0.75 \mathrm{~kg}$ on the high and low PN respectively. There was a significant $\mathrm{I} \times \mathrm{R}$ interaction $(P<0.00 \mathrm{r})$ with the maximum protein gain occurring at $460 \mathrm{~kJ} / \mathrm{g} \mathrm{N}$ when I was constant and at $355 \mathrm{~kJ} / \mathrm{gN}$ when $\mathrm{R}$ was $25 \% / 8 \mathrm{~d}$. The I $\times$ Pinteraction just failed to attain statistical significance $(P=0.067)$ the mean gains of protein being 1.03 , 0.92 and 0.87 respectively with increasing $R$ on the high $P N$ and $0.77,0.79$ and $0.70 \mathrm{~kg}$ on the low PN.

The proportion of apparent digested $\mathrm{N}$ intake retained ( $\mathrm{N}$ retention(NR): apparent digested $\mathrm{N}(\mathrm{ADN})$ ) between 8 and $32 \mathrm{~d}$ reached a maximum of 0.80 (Table 5) compared with a maximum value of 0.90 obtained by the balance method (McCracken et al. 1980 ). The NR:ADN value was significantly $(P<0.00 \mathrm{I})$ affected by all three factors. The $\mathrm{I} \times \mathrm{R}$ interaction was significant $(P<0.00 \mathrm{I})$. The NR:ADN value increased from 0.37 to 0.78 with increasing value for I when $R$ was zero but when $R$ was $25 \%$ per $8 \mathrm{~d}$, the proportion increased from 0.49 to a maximum of 0.80 at $565 \mathrm{~kJ} / \mathrm{g} \mathrm{N}$ and declined to 0.74 at $670 \mathrm{~kJ} / \mathrm{g} \mathrm{N}$. Similarly the $I \times P N$ interaction was significant $(P<0.0 I)$, the NR:ADN value increasing from 0.42 at $250 \mathrm{~kJ} / \mathrm{g} \mathrm{N}$ to 0.78 at $670 \mathrm{~kJ} / \mathrm{g} \mathrm{N}$ on the high $\mathrm{PN}$ but reaching a maximum value of 0.80 at $565 \mathrm{~kJ} / \mathrm{g} \mathrm{N}$ and falling to 0.75 at $670 \mathrm{~kJ} / \mathrm{g} \mathrm{N}$ on the low PN. There was also a significant $I \times R \times P N$ interaction $(P<0.01)$ which was apparent at the highest level of $\mathrm{I}$.

Carcass fat gain and carcass energy gain exhibited a quadratic response to I (Table 6) and reached a maximum at $460 \mathrm{~kJ} / \mathrm{g} \mathrm{N}$. There was also a significant $(P<0.05)$ response of fat gain to increasing levels of $R$ the mean values being $0.40,0.45$ and $0.48 \pm 0.020 \mathrm{~kg}$. The mean values on the high and low PN were 0.58 and $0.30 \pm 0.016 \mathrm{~kg}$ and the difference was significant $(P<0.001)$. Carcass energy gain was also significantly lower $(P<0.00 \mathrm{I})$ on the low PN the mean values being 45 and $30 \pm 0.9 \mathrm{MJ}$.

The energy content of the live-weight gain increased linearly $(P<0.00 \mathrm{I})$ from 5.79 $\mathrm{MJ} / \mathrm{kg}$ to $7.90 \mathrm{MJ} / \mathrm{kg}$ with increasing level of $\mathrm{I}$. PN and $\mathrm{R}$ also produced significant $(P<0.001)$ responses the means being respectively 7.52 and $6.39 \pm 0.08 \mathrm{I} \mathrm{MJ} / \mathrm{kg}$ on the high 


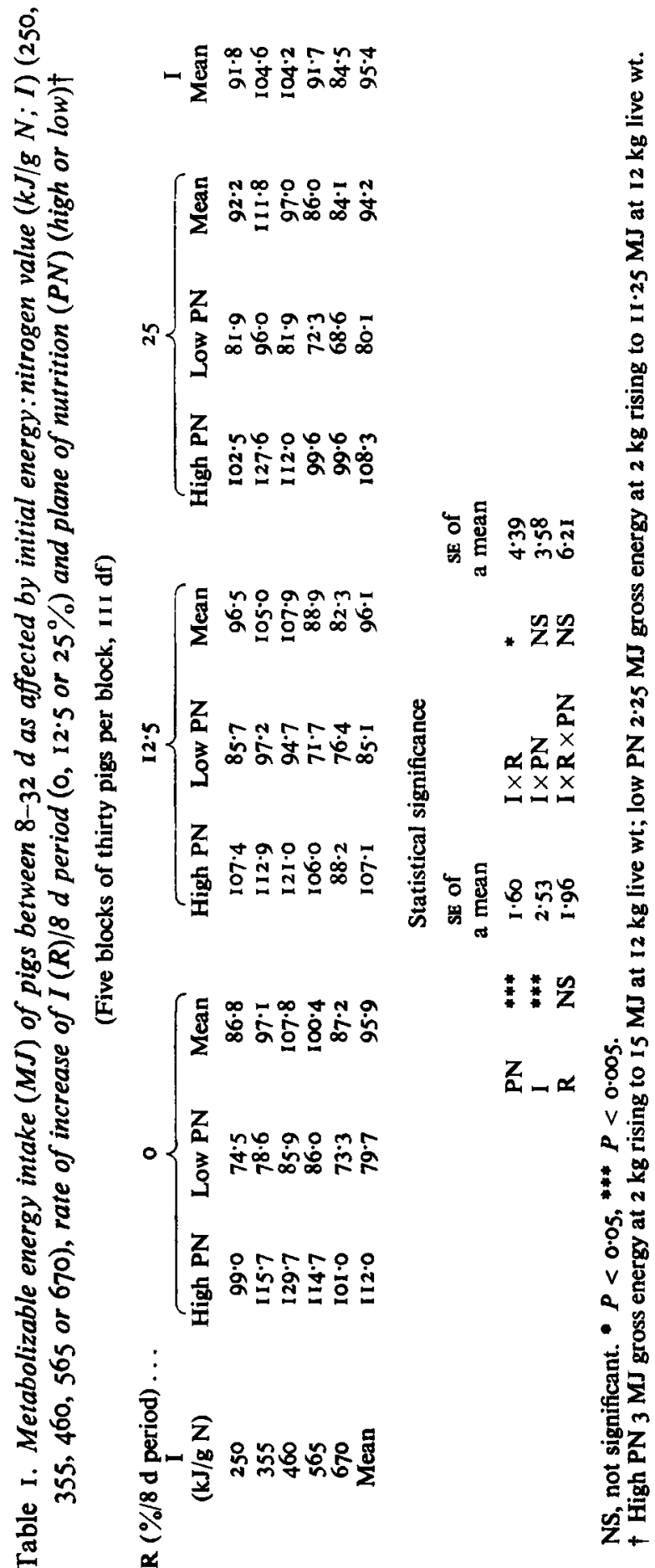




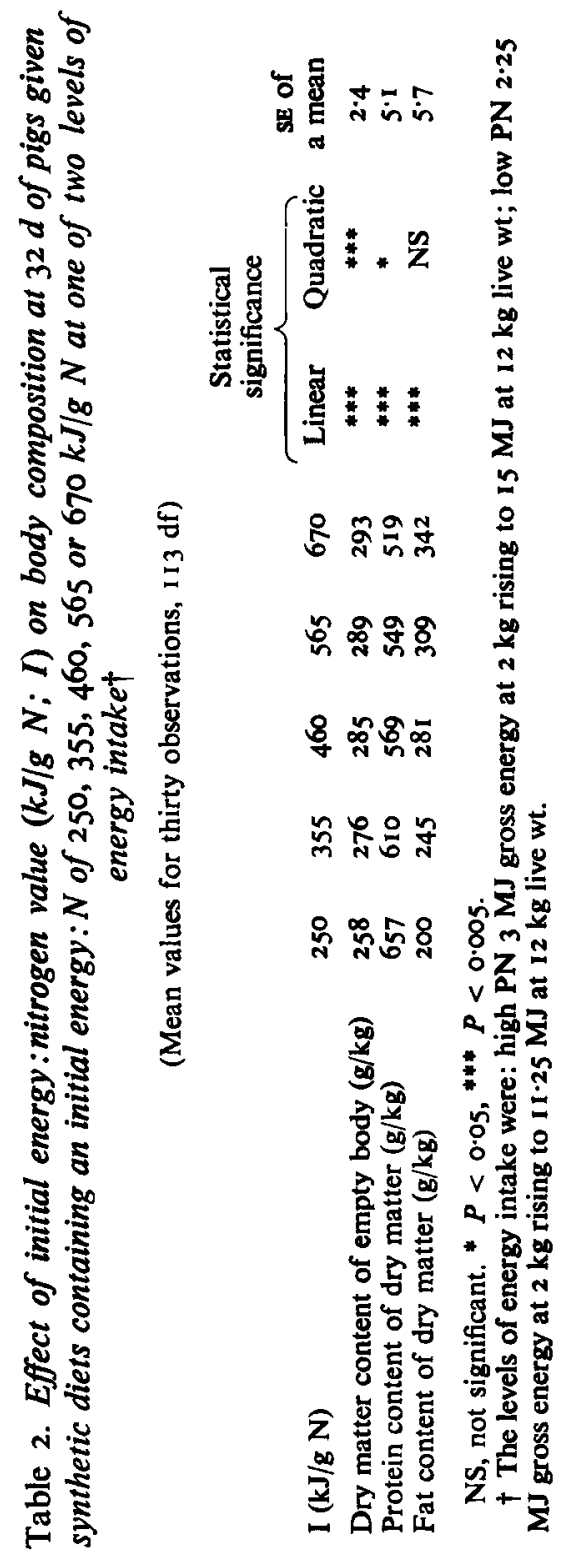


$\checkmark$
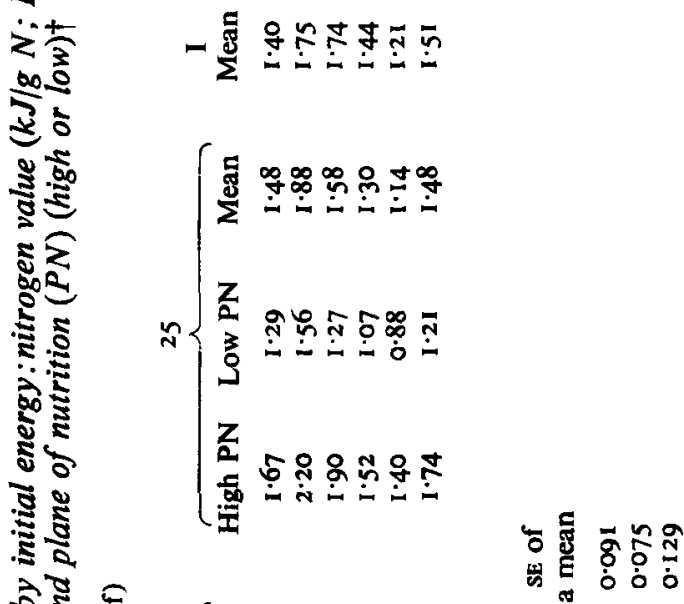

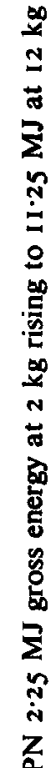

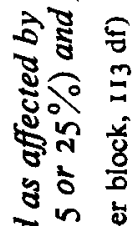

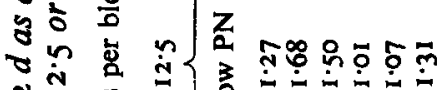

N.

$\infty 0$

छे

s

क्षे

है

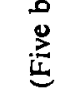

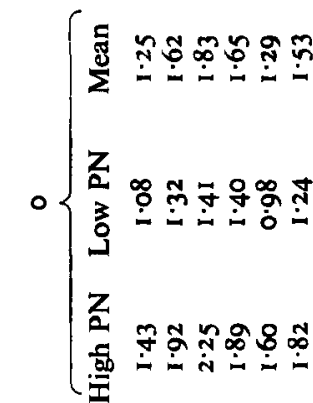

Z

.

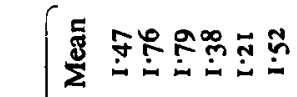

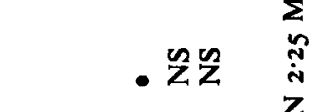

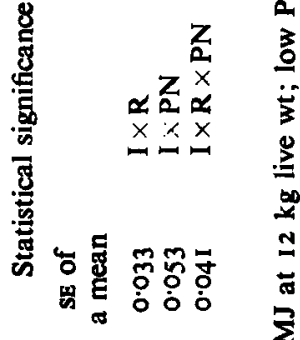

충ำ

放

s。

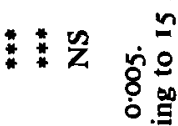

$z-x$

$v \cdot \frac{2}{2}$

$\checkmark$

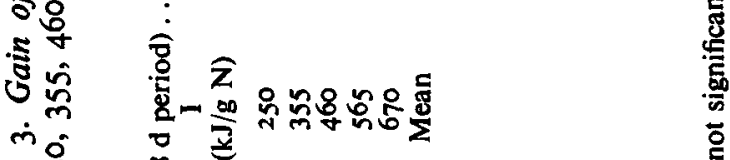

$* \frac{1}{4}$

ชิ่

$\checkmark$

?.

莽实

mi

选 总 
312 K. J. MCCracken, S. M. Eddie and W. G. Stevenson

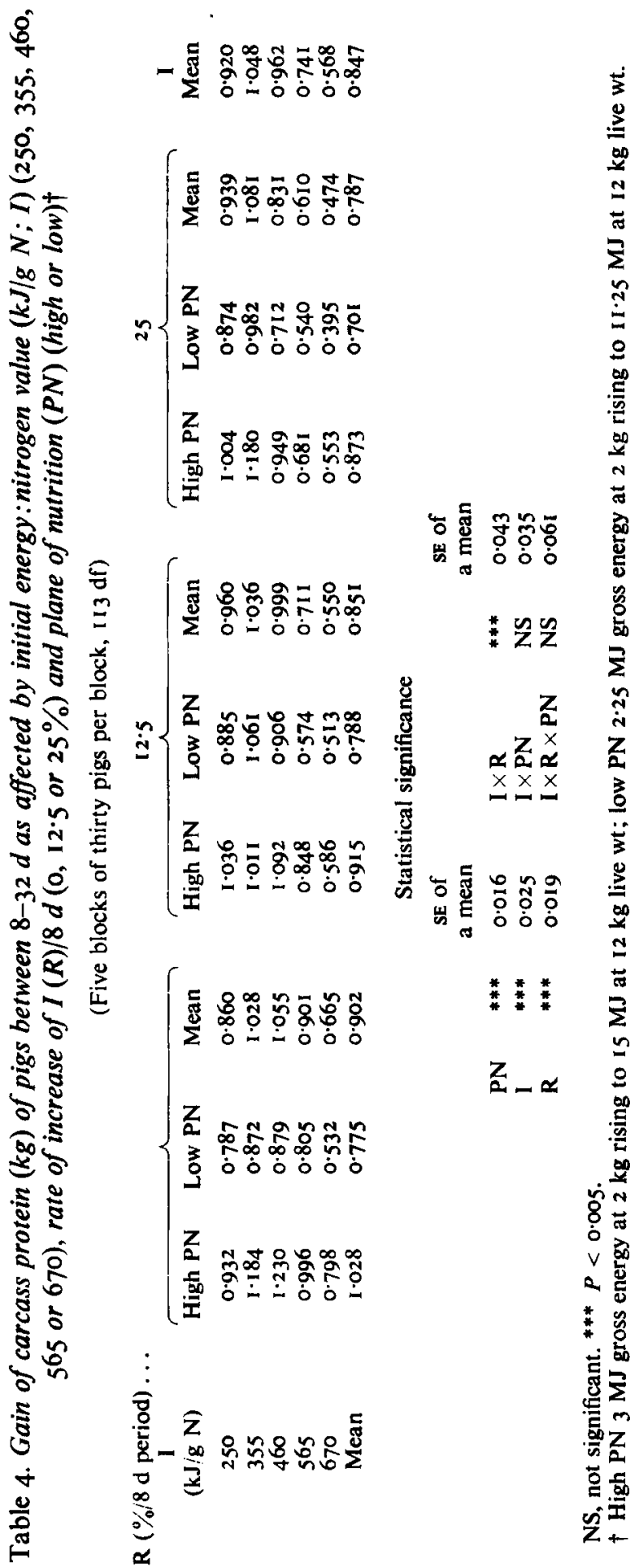




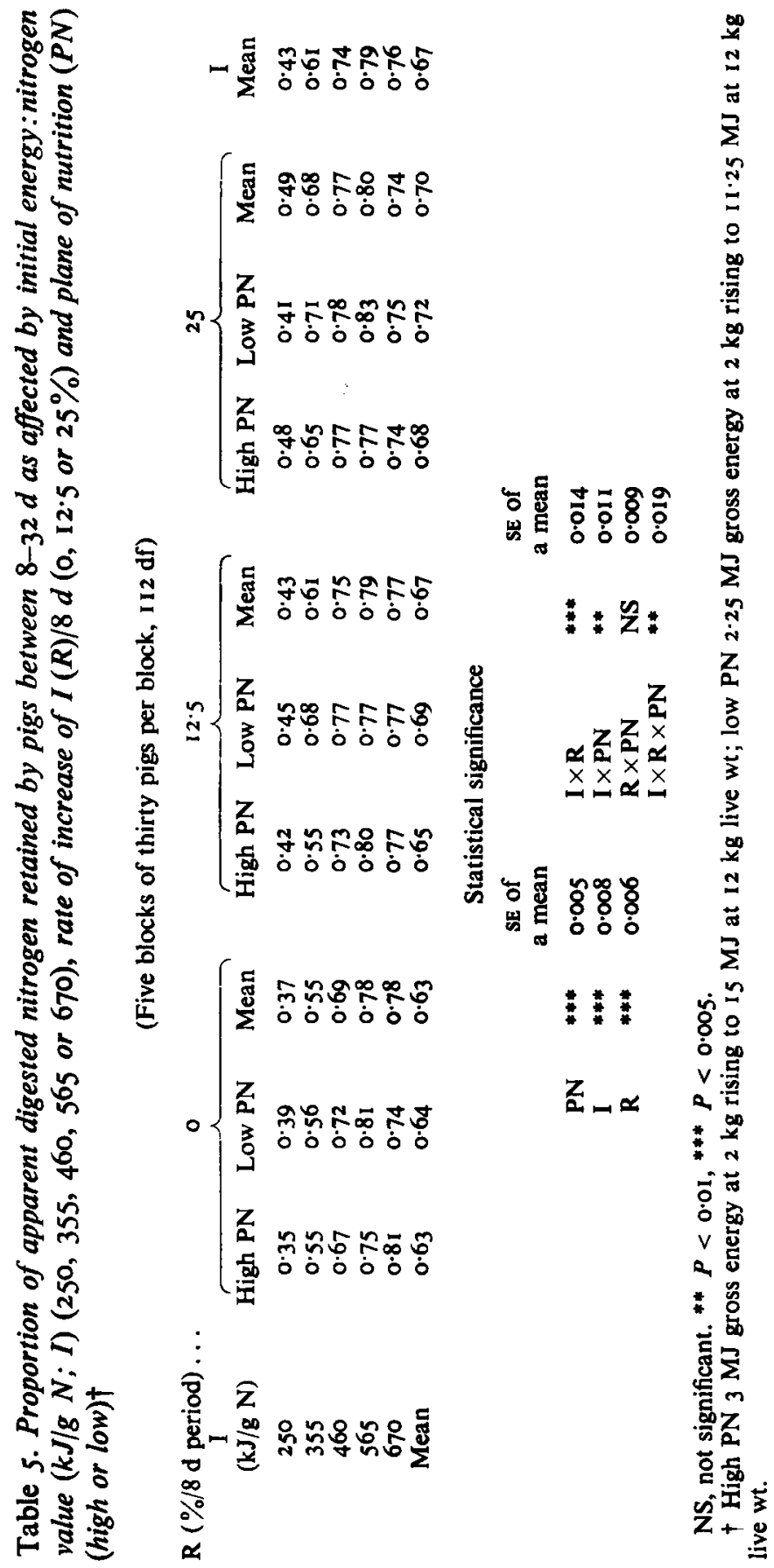




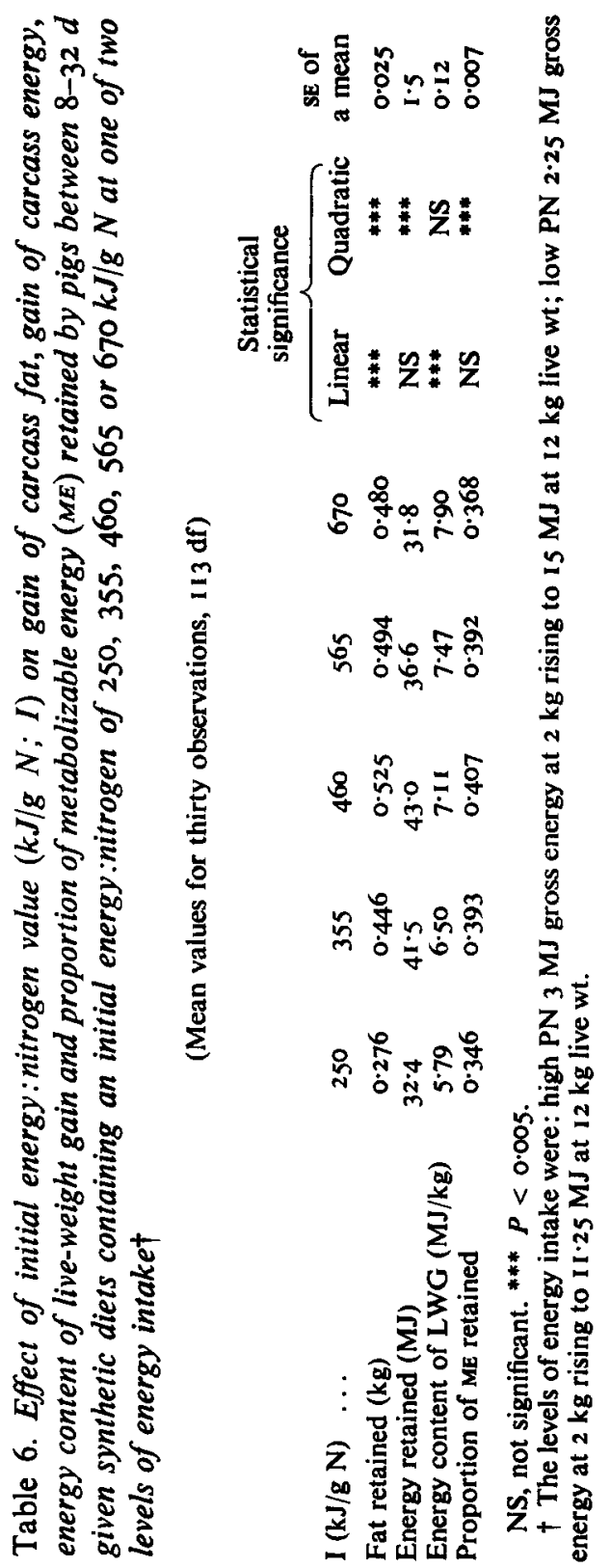


and low PN and 6.55, 6.94 and 7.38 $\pm 0.101 \mathrm{MJ} / \mathrm{kg}$ with increasing value of $\mathrm{R}$. There were no significant treatment interactions in respect of the measurements shown in Table 6.

The proportion of the ME intake retained in the carcass showed a quadratic response $(P<0.00 \mathrm{I})$ to energy: $\mathrm{N}$ reaching a maximum of 0.41 at $460 \mathrm{~kJ} / \mathrm{g} \mathrm{N}$. There was a significant reduction in the proportion retained on the low $P N$, the means being 0.41 and $0.36 \pm 0.005$.

Energy retention (ER; $\left.\mathrm{MJ} / \mathrm{kg} \mathrm{W}^{0.75}\right)$ regressed on $\mathrm{ME}$ intake $\left(\mathrm{MJ} / \mathrm{kg} \mathrm{W}^{0.75}\right)$ gave the relationship:

$$
\begin{aligned}
\mathrm{ER} & =0.68 \mathrm{ME}-0.390, r 0.93 . \\
& \pm 0.023
\end{aligned}
$$

Multiple regression analysis of ME $v$. body-weight $(\mathrm{W} ; \mathrm{kg}$ ) protein gain (PG; $\mathrm{kg}$ ) and fat gain (FG; $\mathrm{kg}$ ) yielded the equation:

$$
\begin{gathered}
\mathrm{ME}(\mathrm{MJ})=0.633 \mathrm{~W}^{0.75}+32.8 \mathrm{PG}+48.3 \mathrm{FG}+0.02, \quad r 0.978 . \\
\pm 0.077 \pm 2.8 \quad \pm 2.0
\end{gathered}
$$

Omitting the intercept term altered the equation to:

$$
\begin{gathered}
\mathrm{ME}(\mathrm{MJ})=0.644 \mathrm{~W}^{0.75}+32.6 \mathrm{PG}+48.2 \mathrm{FG} . \\
\pm 0.028 \pm 2.2 \pm \mathrm{I} \cdot 9 \\
\text { DISCUSSION }
\end{gathered}
$$

The live-weight of the pigs at $8 \mathrm{~d}(2.0 \mathrm{~kg})$ was low in comparison with that of suckled pigs at the same age. The body composition of the pigs slaughtered at $8 \mathrm{~d}$ was very different from that of pigs aged $7 \mathrm{~d}$ analysed by Manners \& McCrea (1963) and those of Wood \& Groves (1965) aged $8 \mathrm{~d}$ which averaged 3.22 and $3.65 \mathrm{~kg}$ respectively. In both instances the carcasses contained approximately $100 \mathrm{~g}$ fat $/ \mathrm{kg}$ and $\mathrm{I} 44 \mathrm{~g}$ protein $/ \mathrm{kg}$ whereas in the present experiment with weaned pigs, the mean values were respectively 62 and $157 \mathrm{~g} / \mathrm{kg}$. It is notable that despite the lack of growth of the weaned pigs to $8 \mathrm{~d}$ the normal pattern of maturation occurred in relation to body water content. In the pigs of Manners \& McCrea (1963) and Wood \& Groves (1965) the body water:protein values at birth were 6.9 and 7.0 and at 7-8 $\mathrm{d}$ were 5.0 and 4.9 respectively. In the weaned pigs water:protein at $8 \mathrm{~d}$ was 4.8 .

The differences in carcass composition between the pigs at $32 \mathrm{~d}$ and the suckled pigs of Wood \& Groves (I965) are even more striking. At $29 \mathrm{~d}$ their pigs weighed $7.60 \mathrm{~kg}$ and the carcasses contained $(\mathrm{g} / \mathrm{kg}): 328 \mathrm{DM}, 160$ fat, 131 protein. In the present experiment the pigs given a constant energy: $\mathrm{N}$ value of $670 \mathrm{~kJ} / \mathrm{g} \mathrm{N}$ (i.e. higher than that normally found in sows' milk) weighed $7.56 \mathrm{~kg}$ at $32 \mathrm{~d}$ and the carcasses contained $(\mathrm{g} / \mathrm{kg}) 294 \mathrm{DM}, 99 \mathrm{fat}, 156$ protein. Kirchgessner \& Kellner (1972) fed diets containing less than $100 \mathrm{~g}$ fat $/ \mathrm{kg}$ and reported carcass analyses in pigs weighing II-I $2 \mathrm{~kg}$ at $42 \mathrm{~d}$ which are consistent with the present results. On the other hand the reports of Braude and co-workers (Braude \& Newport, 1973; Braude et al. 1976; Newport, 1979) who fed diets containing 280-420 $\mathrm{g}$ fat $/ \mathrm{kg}$ are in line with the values reported for suckled pigs (Manners \& McCrea, I963; Wood \& Groves, 1965). The possibility that the differences are due to breed or PN is counteracted by reference to the results of Whittemore et al. (1978). At $28 \mathrm{~d}$ the mean empty-body-weight of suckled pigs from Hampshire and Saddleback sows was $6.6 \mathrm{~kg}$ and the fat and protein contents in the empty-body were 152 and $146 \mathrm{~g} / \mathrm{kg}$ respectively. Large White/Landrace pigs at $21 \mathrm{~d}$ weighed $5.5 \mathrm{~kg}$ and the fat and protein contents were respectively 148 and $143 \mathrm{~g} / \mathrm{kg}$. Jordan $\&$ Weatherup ( $1976 b$ ) found that when diets of the same energy: $N$ value were given to pigs at approximately $14 \mathrm{~d}$, increasing the level of dietary fat above $100 \mathrm{~g} / \mathrm{kg}$ progressively reduced protein deposition and increased fat deposition. It would seem, therefore, that there are potential benefits in terms of lean meat production from the use of fairly low levels of fat in the diet of early-weaned pigs.

The response curves of protein gain and NR:ADN in relation to $I$ and $R$ are shown in Fig. 1. Despite the differences in the absolute values of protein gain obtained by balance and 


\section{K. J. M CCracken, S. M. Eddie and W. G. Stevenson}

by slaughter, the shapes of the curves obtained are substantially the same as those reported by McCracken et al. (1980). The optimum energy: $\mathrm{N}$ values for protein gain can be calculated as 422,345 and $265 \mathrm{~kJ} / \mathrm{g} \mathrm{N}$ for $\mathrm{R}$ values of $0,12.5$ and $25 \% / 8 \mathrm{~d}$ respectively; at these values the NR:ADN values are respectively $0.65,0.59$ and 0.52 . If on the other hand an NR:ADN value of 0.77 is taken as the criterion of satisfactory performance the corresponding energy: $N$ values are 560,500 and $450 \mathrm{~kJ} / \mathrm{g} \mathrm{N}$ and the protein gain in all three instances is approximately $88 \%$ of the maximum value. It is evident, therefore, that in the young pig there is a fairly wide range of dietary protein content which may be regarded as satisfactory and that practical recommendations will depend mainly on economic considerations and possible long-term effects on lean meat production at present not fully elucidated (McCracken et al. 1980).

Despite the fairly severe restriction of energy intake on the low PN the reduction in protein gain was less than the reduction in intake and the NR:ADN value was significantly higher $(P<0.00 \mathrm{I})$. This is emphasized in Fig. 2 where the protein gain is related to protein intake at the two levels of energy intake. Although the $\mathrm{PN} \times \mathrm{R} \times \mathrm{I}$ interaction failed to attain statistical significance, it appeared that the best performance was attained on the low PN by the pigs given an I value of $355 \mathrm{~kJ} / \mathrm{g} \mathrm{N}$ changing by $12.5 \% / 8 \mathrm{~d}$, whereas on the high PN the highest rates of protein gain were achieved with a constant energy: $N$ value of 460 $\mathrm{kJ} / \mathrm{N}$. Taken in conjunction with the results reported by McCracken et al. (1980) for the NR: ADN value at I I-I6, I9-24 and 27-32 d, this tends to suggest that a low initial dietary energy: $\mathrm{N}$ value increasing by approximately $10 \% /$ week would provide the best compromise in terms of efficiency of NR especially if pigs are being subjected to a mild restriction of energy intake.

Whereas protein gain declined rapidly at the highest levels of energy: $N$, fat gain was almost unaffected with the result that the proportion of fat:protein and hence the energy content of the gain increased rapidly with increasing value of $I$. This observation is in line with the results of other workers (Kirchgessner \& Kellner, 1972; Newport, 1979). On the other hand the effect of PN on fat gain was much greater than on protein gain. On the low PN, fat gain at all levels of protein intake was approximately half that on the high PN. As a result, the energy content of the gain was, on average, $15 \%$ lower on the low PN and $22 \%$ lower when the levels of I giving maximum protein gain were compared. This was partially offset by a I $2 \%$ reduction in the proportion of ME retained but nevertheless brought about an improvement in the FCR as discussed previously (McCracken et al. 1980).

The values for the proportion of ME retained are similar to those reported by Muller \& Kirchgessner (1974) but whereas they obtained a linear decrease in efficiency with increasing dietary protein content the present results show a maximum proportion of ME retained at an energy:protein value of $460 \mathrm{~kJ} / \mathrm{g} \mathrm{N}$ on the high $\mathrm{PN}$ and $355 \mathrm{~kJ} / \mathrm{g} \mathrm{N}$ on the low $\mathrm{PN}$, i.e. corresponding to the highest rates of crude protein and live-weight gain and of energy intake. This difference may be due to the wider range and larger number of energy: $N$ values used here. In both experiments, however, there was a marked reduction in efficiency at the highest levels of dietary protein presumably due to the cost of urea production under conditions of excess protein intake (Kirchgessner \& Muller, 1974).

The regression of energy retention on ME intake yielded a coefficient of 0.68 for the net availability of ME for maintenance and production (NAME) and a calculated maintenance requirement of $574 \mathrm{~kJ} / \mathrm{kg} \mathrm{W}^{\mathbf{0 . 7 5}}$. This value for maintenance is identical to that calculated from the original results of Kielanowski (1965) but is somewhat higher than that obtained by Kielanowski \& Kotarbinska (1970) using a modified regression technique and by Jordan \& Brown (1970) using indirect calorimetry. The value for NAME is higher than that calculated by Muller \& Kirchgessner (1974) using similar diets and assuming a maintenance requirement of $130 \mathrm{kcal}(544 \mathrm{~kJ}) / \mathrm{kg} \mathrm{W}^{0 \cdot 75}$, similar to values reported by Böhme et al. (1976), but 


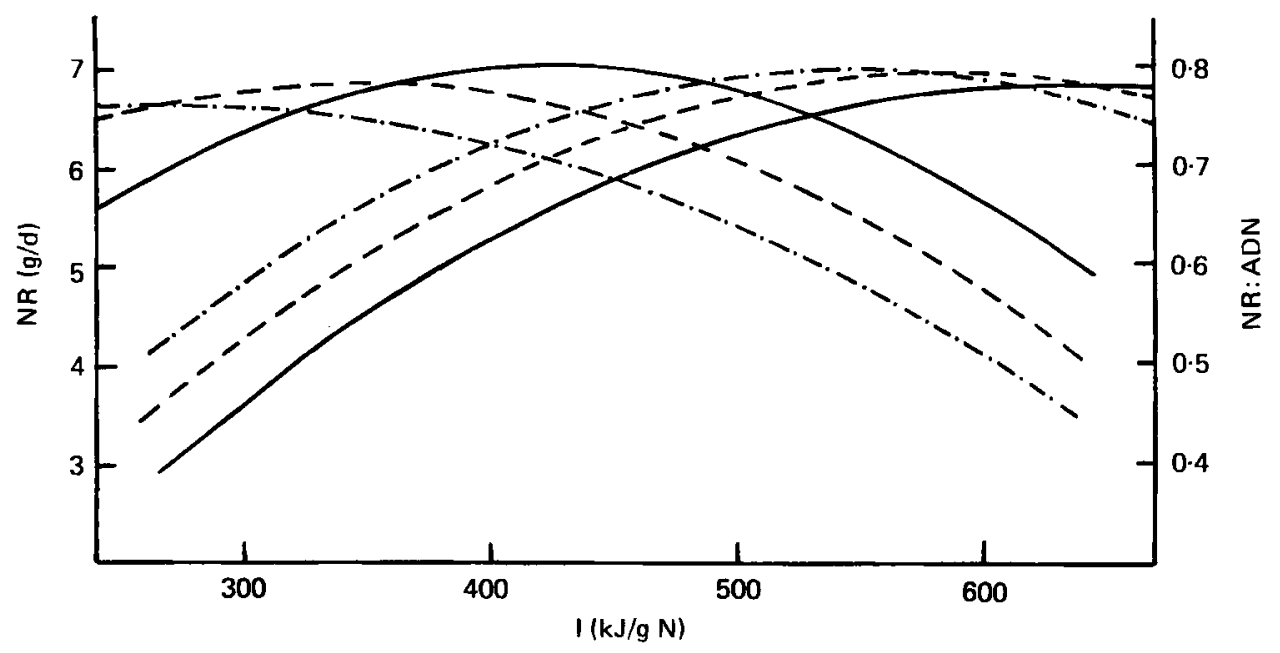

Fig. I. Response curves of nitrogen retention ( $\mathrm{g} / \mathrm{d}$; NR):apparent digested $\mathrm{N}$ (ADN) (NR:ADN) in relation to initial energy: nitrogen value $(\mathrm{kJ} / \mathrm{g} \mathrm{N}$; $\mathrm{I}$ in the diet, calculated from least squares regressions. - constant I; ---, I increased by $12.5 \%$ at 16 and $24 \mathrm{~d} ;-\cdot-\cdot-$, I increased by $25 \%$ at 16 and $24 \mathrm{~d}$.

$$
\begin{array}{ll}
\text { Nitrogen: } & Y=-0.649+0.03633 X-0.00004303 X^{2} \\
\text { retention } & Y=3.047+0.02173 X-0.00003153 X^{2} \\
\text { (g/d) } & Y=5.001+0.1217 X-0.00002292 X^{2} \\
\text { NR:ADN: } & Y=-36.363+0.3618 X-0.0002819 X^{2} \\
& Y=-31.081+0.3760 X-0.0003222 X^{2} \\
& Y=-24.857+0.3853 X-0.0003538 X^{2}
\end{array}
$$

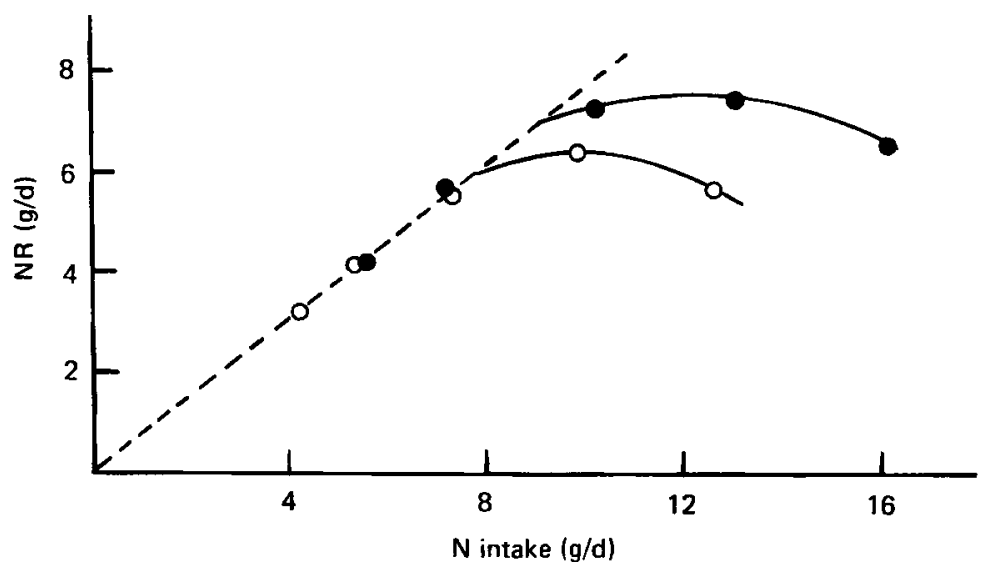

Fig. 2. Effect of the plane of nutrition (PN) and nitrogen intake $(g / d)$ on nitrogen retention (NR;g/d) of piglets between 8 and $32 \mathrm{~d}$ of age. ( $)$, high PN $(3 \mathrm{MJ} / \mathrm{d}$ at $2 \mathrm{~kg}$ rising to $15 \mathrm{MJ} / \mathrm{d}$ at $12 \mathrm{~kg}) ;(\mathrm{O})$, low $P N(2 \cdot 25 \mathrm{MJ} / \mathrm{d}$ at $2 \mathrm{~kg}$ rising to $11 \cdot 25 \mathrm{MJ} / \mathrm{d}$ at $12 \mathrm{~kg})$.

much lower than those obtained by Jordan \& Brown (1970), Jordan (1974) and Jordan \& Weatherup ( $1976 b$ ) who fed diets based on cow's milk. Part of this difference may be explained by the results of Jordan \& Weatherup (1976a) who found that the NAME increased from $0.80-0.89$ as the dietary fat content was increased from $16-440 \mathrm{~g} / \mathrm{kg}$. 
Table 7. Estimates of the maintenance $(M)$ requirement $\left(k J / k g\right.$ body-weight $\left.{ }^{0.75}\right)$ and the energetic efficiency of protein synthesis $\left(\mathrm{k}_{\mathrm{p}}\right)$ in young pigs given milk-based diets, compiled from various sources

\begin{tabular}{|c|c|c|c|}
\hline $\begin{array}{c}\text { Body-wt } \\
\text { (kg) }\end{array}$ & $\mathbf{M}$ & $k_{p}$ & Source \\
\hline $2-9$ & 575 & 0.76 & Kielanowski (1965) \\
\hline $2-9$ & 498 & 0.57 & Kielanowski \& Kotarbinska (1970) \\
\hline $4-12$ & $\begin{array}{l}481 \\
544\end{array}$ & $\left.\begin{array}{l}0.48 \\
0.54\end{array}\right\}$ & Muller \& Kirchgessner (1974) \\
\hline $4-12$ & $\begin{array}{l}481 \\
544\end{array}$ & $\left.\begin{array}{l}0.53 \\
0.58\end{array}\right\}$ & Kirchgessner \& Muller (1974) \\
\hline $2-10$ & 644 & 0.72 & Present results \\
\hline
\end{tabular}

However, a study of the various reports indicates that most of the differences are attributable to the partition of energy intake between the maintenance requirement and NAME. For example, recalculation of the results of Jordan \& Weatherup (1976b) using a value of $570 \mathrm{~kJ} / \mathrm{kg} \mathrm{W}^{0.75}$ for maintenance reduces the NAME from 0.80 to 0.72 and similarly in the present experiment increasing maintenance from 574 to $644 \mathrm{~kJ} / \mathrm{kg} \mathrm{W}^{0.75}$ increases the NAME from 0.68 to 0.76 .

The multiple regression of $\mathrm{ME}$ intake on maintenance requirement and protein and fat deposition was determined using coefficients of $I \cdot 0,0.75$ and 0.56 . The equation based on $\mathrm{W}^{\mathbf{0 . 7 5}}$ was chosen as it gave the smallest intercept and was more convenient for the purpose of comparing with other values in the literature. The maintenance term, $644 \mathrm{~kJ} / \mathrm{kg} \mathrm{W^{0.75 }}$ is somewhat higher than that obtained by regressing stored energy on ME intake. The partial efficiency for fat deposition ( $0.8 \mathrm{I})$ remained remarkably constant irrespective of the regression function used and is similar to values reported for older pigs (Thorbek, 1970; Thorbek, 1975), chicks (Bønsdorff Petersen, 1970) and lambs (Ørskov \& McDonald, 1970; Walker \& Norton, I97I). This constancy of the energy cost of fat deposition has been previously discussed (Kielanowski, 1967; Breirem \& Homb, 1972).

The energy cost of protein deposition corresponds to a partial efficiency of 0.72 which is similar to the original estimate of Kielanowski ( 1965 ) for the young pig, to that obtained by Walker \& Norton (197I) in the milk-fed lamb and to the results of McCracken (I973) with young rats given synthetic diets. It is higher than the estimates of Kielanowski \& Kotarbinska (1970), Muller and Kirchgessner (1974) and Kirchgessner \& Muller (1974) with young pigs given milk-based diets (Table 7). However, the interdependence of the partial efficiency of protein deposition and the maintenance term has been previously discussed (Pullar \& Webster, 1974; Kielanowski, 1976) and is clearly discernible in the results summarized in Table 7 . It would seem that a definitive assessment of the energy cost of protein deposition in the young pig must await improved estimates of the maintenance energy costs.

The authors wish to thank Messrs L. Jarvis and T. Walker for careful attention to the experimental animals and Messrs W. Clarke and P. A. Dinsmore for analytical services.

\section{REFERENCES}

Böhme, H., Gadeken, D. \& Oslage, H. J. (1976). Eur. Ass. Anim. Prod. publ. no. I9, p. I75. Bønsdorff Petersen, C. (1970). Eur. Ass. Anim. Prod. publ. no. 13, p. 205.

Braude, R., Keal, H. D. \& Newport, M. J. (1976). Br. J. Nutr. 35, 253.

Braude, R. \& Newport, M. J. (1973). Br. J. Nutr. 29, 447. 
Breirem, K. \& Homb, T. (1972). In Handbuch der Tierernährung, vol. 2, p. 547. [W. Lenkeit, K. Breirem and E. Crasemann, editorsl. Hamburg and Berlin: Verlag Paul Parey.

Brouwer, E. (1965). Eur. Ass. Anim. Prod. publ. no. I I, p. 44I.

Duncan, D. L. (I966). In Recent Advances in Animal Nutrition, p. 5I. [J. T. Abrams, editor]. London: J. A. Churchill.

Florence, E. \& Mitchell, K. G. (1972). Proc. Br. Soc. Anim. Prod. 1, 101.

Fuller, M. F. \& Boyne, A. W. (1971). Br. J. Nutr. 25, 259.

Jordan, J. W. (1974). Eur. Ass. Anim. Prod. publ. no. 14, p. 189.

Jordan, J. W. \& Brown, W. O. (1970). Eur. Ass. Anim. Prod. publ. no. 13, p. 16 I.

Jordan, J. W. \& Weatherup, S. T. C. (1976a). Rec. agric. Res. $24,45$.

Jordan, J. W. \& Weatherup, S. T. C. (1976b). Eur. Ass. Anim. Prod. publ. no. 19, p. 169.

Kielanowski, J. (1965). Eur. Ass. Anim. Prod. publ. no. II, p. 13.

Kielanowski, J. (1967). Proc. 9th Int. Congr. Anim. Prod., Edinburgh, 1966, p. 212.

Kielanowski, J. (1976). Eur. Ass. Anim. Prod. publ. no. 16, p. 207.

Kielanowski, J. \& Kotarbinska, M. (1970). Eur. Ass. Anim. Prod. publ. no. 13, p. 145.

Kirchgessner, M. \& Kellner, B.B. (1972). Archs. Tierernäh. 22, 249.

Kirchgessner, M. \& Muller, H. C. (1974). Archs. Tierernäh, 24, 215.

McCracken, K. J. (1973). Proc. Nutr. Soc. 32, 66A.

McCracken, K. J. \& Eddie, S. M. (1974). Eur. Ass. Anim. Prod. publ, no. 14: p. I8I.

McCracken, K. J., Eddie, S. M. \& Stevenson, W. G. (1980). Br. J. Nutr. 43, 289.

Manners, M. J. \& McCrea, M. R. (1963). Br. J. Nutr. 17, 495.

Muller, H. L. \& Kirchgessner, M. (1974). Eur. Ass. Anim. Prod. publ. no. 14.

Nehring, K., Lambe, W., Schwerdtfeger, E., Schiemann, R., Haesler, E. \& Hoffmann, L. (1957). Biochem. Z. 328, 549 .

Newport, M. J. (1979). Br. J. Nutr. 41, 95.

Ørskov, E. R. \& McDonald, I. (1970). Eur. Ass. Anim. Prod. publ. no. 13, p. 121.

Pullar, J. D. \& Webster, A. J. F. (1974). Br. J. Nutr. 3r. 377.

Schneider, D. L. \& Sarett, H. P. (1969). J. Nutr. 98, 279.

Thorbek, G. (1970). Eur. Ass. Anim. Prod. publ. no. 13, p. 129.

Thorbek, G. (1975). Beretn. Forsegslab, no. 424.

Walker, D. M. \& Norton, B. W. (1971). J. agric. Sci., Camb. 77, 368.

Whittemore, C. T., Aumaitre, A. \& Williams, I. H. (1978). J. agric. Sci., Camb. 91, 681.

Wood, A. J. \& Groves, T. D. D. (1965). Can. J. Anim. Sci. 45, 8. 